\title{
Chimpanzee Referents and the Emergence of Human Hunting
}

\author{
Travis Rayne Pickering*,1,2 and Manuel Domínguez-Rodrigo ${ }^{3}$
}

\author{
${ }^{I}$ Department of Anthropology, University of Wisconsin-Madison, 1180 Observatory Drive, 5240 Social Building, \\ Madison, Wisconsin, 53706, USA; ${ }^{2}$ Institute for Human Evolution, University of the Witwatersrand, Private Bag 3, \\ WITS 2050, Johannesburg, South Africa; ${ }^{3}$ Department of Prehistory, Complutense University, 28040, Madrid, Spain
}

\begin{abstract}
The use of referent taxa, and especially chimpanzee referents, in modeling human evolution has been harshly criticized. No doubt, chimpanzee data are often misused in models of early hominid behavior. But, those misuses are examples of careless, formal analogizing. In contrast, it is equally possible to create non-trivial chimpanzee analogies. These analogies can, in turn, be linked together to construct credible models of human evolution, from which emanate hypotheses that are testable using paleoanthropological data. Unique among potential referents, chimpanzees are very closely related to early hominids and some populations reside in ecological contexts that are comparable to those of our African ancestors. It is these two variables that form the core of evolutionary behavioral ecology. We exploit chimpanzee and early hominid continuities and employ non-trivial analogies to provide a model of basal hominid hunting. The model is testable and the topic is worthy because hunting and meat-eating are argued by some to be the basis of human sociality.
\end{abstract}

Keywords: Uniformitarianism, modeling, human evolution, predation, meat-eating.

\section{INTRODUCTION}

Human hunting is unique. Some nonhuman animals use tools to hunt, others target prey larger than an individual hunter and a few share food, but none possesses these traits as a behavioral complex, used in combination for predation, as do humans. Many researchers argue that the multifaceted, socially complex hunting of modern human foragers is the socioecological basis of our humanness: "it is the behavioral trajectory taken by humans to secure high-quality foodsrather than simply the foods themselves-that has made humans human...Evolving humans appear to have relied increasingly on brain power as the key element in their dietary strategy, using technological and social innovations to secure and process foods before ingestion" [1: 114-115]. Modern foraging societies developed out of this system, in which carbohydrate-rich plants were the most important fuel supporting an increasingly larger brain. Regular consumption of meat alleviated the high-cost search and recovery of those plants, which are patchily distributed and oscillate seasonally in their availability. This is because meat is so dense nutritionally. Even a small amount of it (or marrow or brains) efficiently satisfies daily requirements for essential fatty acids and basal energy.

The earliest known archaeological traces of hominid meat-eating are from Gona and Bouri, 2.6 - 2.5 million year old localities in the Afar Rift of Ethiopia [2-4]. At those sites, stone tool butchery marks occur on ungulate bones, including those derived from animals that were larger than the individual hominid(s) who rendered them. The placement of the butchery marks on the midshaft portions of humeri, radiolunae, femora and tibiae, on the lingual surface of a

*Address correspondence to this author at the Department of Anthropology, University of Wisconsin-Madison, 1180 Observatory Drive, 5240 Social Building, Madison, Wisconsin, 53706, USA; Tel: (608) 262-5818;

Fax: (608) 265-4216; E-mail: tpickering@wisc.edu mandible and on the ventral surface of a rib implies filleting of fully fleshed limbs and the removal of the tongue and upper viscera from carcasses. We can extrapolate from those observations that hominids probably (at least occasionally) acquired carcasses before other competitors, such as large cats and hyenas, who themselves would have stripped carcasses of preferred soft tissues, leaving their own distinctive tooth marks on bones. In brief, the earliest evidence of hominid meat-eating and, by extension, hunting suggests a humanlike capability for predation: that is, early, unfettered access to fleshed carcasses. Currently, it is impossible to infer if the attendant, long-distance transport and socially complex sharing of meat and marrow that characterizes much of modern human hunting was a component of hominid behavior at Gona and Bouri. Some researchers argue that a hunting-based, humanlike sociality, with meat-sharing at fixed central places, is only apparent some 800,000 years later. Unlike the initial stage of stone tool technology, sampled sketchily at the earlier Afar Rift sites, 1.8 - 1.6 Ma (mega annum) is an interval well-represented archaeologically. During this stage, "Multiple archaeological sites...including FLK Zinj [Olduvai Gorge, Tanzania] and FxJj 50 [Koobi Fora, Kenya], yield much larger concentrations of thousands of stone tools and MNI [minimum number of individual] estimates, ranging up to four dozen large animals in temporally restricted assemblages. Combined with extensive evidence of butchery for meat and marrow, this demonstrates regular access to mostly intact carcasses and repeated transport of portions to favored, central locations (i.e., intermittent, daytime home bases)" [5: 207].

Researchers will continue to debate these interpretations. Regardless, it is clear that if hunting is really (or might really be) an integral part of defining humanness, then paleoanthropologists should have a keen interest in understanding its earliest expression, the behavioral complex from which the humanlike form ultimately emerged. Hominid meat-eating at 
the two chronological waypoints represented in the late Pliocene by Gona and Bouri and in the early Pleistocene by FLK Zinj and FxJj 50 is archaeologically visible because those sites possess stone tools and butchered bones. Hominidbearing geological deposits in excess of 2.6 Ma exist and some are in areas that have been subjected to intensive paleoanthropological survey-but none thus far has yielded archaeological evidence of hominid tool use or meat-eating. A predictive model should aid in the recognition of hominid meat-eating that occurred prior to the advent of nonperishable lithic technology.

In this paper, we provide such a model. But, first we offer theoretical defense of our choice to employ a chimpanzee referent as the model's base. We believe this is a necessary requirement. It has been over twenty years since Tooby and DeVore's [6] influential critique of referential modeling in human evolutionary studies. Even though the censure of such models was initially expanded by numerous commentators, others have lamented a more recent shift away from conceptual modeling. In a prominent example, Sayers and Lovejoy [7] take specific and forceful issue with the use of chimpanzee referents in models of early hominid socioecology and behavior. The effort to build conceptual models, based on general evolutionary and ecological principles, is laudable. But since these principles are ultimately gleaned from data on specific biological taxa anyway, an a priori bias against chimpanzees_-our closest living relative, with whom we share a relatively recent common ancestor and who is represented by some populations that inhabit ecosystems similar to that of early hominids-needlessly diverts focus from the very area it should be most intensely directed.

\section{IN DEFENSE OF CHIMPANZEES}

There is no question of pervasive "chimpocentrism" in paleoanthropology. Critics provide a valuable service in reminding us of its potential pitfalls, but they also tend to veer toward the overblown in their admonishments. The obvious argument in favor of a focus on chimpanzees is a cladistic one-they are the closest living relatives of humans [8]. That means that much of chimpanzee morphology and behavior might represent the plesiomorphic condition relative to humans, their sister taxon. Thus, using chimpanzee morphology and behavior to model the last common ancestor of hominids and chimpanzees, as well as basal hominids, is not an unreasonable approach.

Chimpanzee plesiomorphy is not, however, demonstrated conclusively. Even though evidence of hominoid evolution in the Late Miocene continues to accrue dramatically since the early 1990s, the chimpanzee fossil record is still scant and relatively recent [9]. In addition, the recent, expanded descriptions and interpretations of the functional morphology of Ardipithecus ramidus [10, and references therein] - a very early hominid species (4.4 Ma) that shows no indication of descent from an ancestor that knucklewalked terrestrially or engaged in arboreal suspension and vertical climbingdemonstrate the unique and highly divergent evolutionary pathways of extant African apes and hominids after these lineages split sometime >6.0 Ma. Given these observations and data, we offer alternative rationales to chimpanzee plesiomorphy that still defend chimpanzee referential modeling as one of the most practical approaches to the study of some important aspects of early hominid evolution.
First, we dispense with the obvious: fossils (and artifacts) are the only direct evidence of human evolution and chimpanzees are not fossils. Neither are modern human foragers, but we believe that they, too, can be useful referents in modeling some aspects human evolution. Detractors debase the study of modern humans in modeling, accusing that the "tyranny of ethnography" [11] works to obfuscate the uniqueness of early hominids. We believe that much of this indignation is hyped against straw men. No sober thinking scientist suggests that we can simply overlay the abilities of modern people-with their large brains and sophisticated technologies-directly across millions of years onto our relatively small-brained and culturally impoverished ancestors. Likewise, everyone (hopefully) concedes that the behavioral and morphological adaptations of chimpanzees-molded over the six million or so years of that taxon's inimitable evolutionary history-will never provide flawless analogs for those of Ardipithecus or Australopithecus. Instead, most researchers simply recognize a profound truism. It is only in the present world that we can actually observe behavior and events as they transform into material consequences. In contrast, the paleontological and archaeological records-the databanks for reconstructing the lives of early humans - are comprised completely and only of the static material consequences of unobservable past behaviors and events. It is, however, those unobservable dynamic aspects of the past that interest us: how did our ancestors adapt and evolve? Actualistic research is, of course, the most common (and only pragmatic) way in which the disconnection between the goals of the paleoanthropologist (reconstructing the lives of extinct hominids) and his sources of data (behaviorless bones and artifacts) is bridged.

It is not our intent here to review actualism in paleoanthropology, a topic that receives comprehensive coverage in many other sources [12, and references therein]. Instead, we stress the essential analogical character of actualism and paleoanthropology. Indeed, some argue that all scientific reasoning is based on analogical modeling [13,14]. In modern scientific analogical modeling, it is possible to differentiate between "descriptive models" and "explanatory models" [13]. Although applied at a higher inferential scale, descriptive and explanatory models are similar, respectively, to formal and structural analogies in theoretical archaeology. A formal analogy merely transcribes an observed analog to the past, while a structural analogy is an inference built upon analogical reasoning $[15,16]$. The dichotomy between formal and structural analogies is portrayed more bluntly by some using the alternative terms "trivial" versus "non-trivial" analogies $[13,17]$. From the perspective of scientific realism, appropriate analogical reasoning is based on the elaboration of testable models, rather than on the application of trivial (formal) analogies. Testable models are fashioned through the dialectic use of groups of linked, non-trivial (structural) analogies. In paleoanthropology, that linkage is created by incorporation of two essential variables: ecological context and phylogenetic relationship. Relevantly, it is those two variables that also form the core of evolutionary behavioral ecology.

Several prominent models of human evolution that employ chimpanzee referents fail to recognize these principles. Instead, they simply overlay trivial analogies on to the hominid fossil record; there is no effort to transform sets of non- 
trivial analogies into models. A recent example is a purported chaîne opératoires for chimpanzee tool behavior that is applied to explain the Oldowan archaeological record [18], even though the latter reveals striking differences with chimpanzee stone tool culture in terms of tool raw material selection, transport and use [19-21]. This follows another wellpublicized instance of trivial analogizing, in which stone flakes created as unintentional consequences of chimpanzee nut-cracking were compared to intentionally created Oldowan flakes [22]. A similar situation is the superimposed claims of cooperative hunting and merit-based meat-sharing among Taï Forest (Côte d'Ivoire) chimpanzees onto past hominids [23], and the proposition that because female chimpanzees use tools more often than male chimpanzees, early hominid females were, likewise, the primary tool-users.

In contrast to these scenarios, we offer a model of early hominid hunting that is constructed of linked, non-trivial chimpanzee analogies and that is testable using paleoanthropological data. With this example, we strive to demonstrate that abandonment of chimpanzee referents in human evolutionary studies disregards subtle but critical differences between types of analogy. That rejection will lead to epistemological failure in paleoanthropology unless the conceptual vacuum it creates is filled with alternative sets of analogies. While we encourage exploration of these alternatives, ecological and phylogenetic realities stress the continued and immediate practicality of chimpanzees for illuminating some important aspects of human evolution.

\section{WHY DO CHIMPANZEES HUNT?}

Many types of animals hunt, and conceptual modelers have turned to some of them in defiance of the "chimpocentric" approach in paleoanthropology. However, the relevance of most predatory vertebrates for modeling early hominid hunting is diminished by their positions on the Tree of Life. As discussed above, phylogenetic proximity is one of the two critical variables for securely linking non-trivial analogies into a coherent model of human evolution. Combine the vast phylogenetic distance between hominids and taxa like vultures and lions-which have been used respectively as analogs for hominid tool use and cooperative hunting-with the striking dissimilarities in their functional morphology, and any behavioral similarities between these taxa become increasingly trivial.

It is, however, possible to build much more relevant models of early hominid hunting using sets of integrated, non-trivial chimpanzee analogies. True, it is improbable that doing so can ever provide the definitive portrayal of early hominid hunting, but we contend the greater credibility of these kinds of models-and the testable hypotheses that emanate from them-should bring us ever closer to the scientific realism of our evolutionary past.

Understanding why chimpanzees hunt is the fundamental step in creating a Pan-based model of early hominid hunting. Field studies conducted in the late 1980s and early 1990s suggested an ecological trigger for chimpanzee predation. Comparative data from several long-term projects indicated that hunting was more frequent in communities that inhabited seasonal, rather than dense, tropical forests [24]. Some studies suggested more specifically that hunting frequency increased with a decrease in fruit availability, regardless of which season that might occur at any particular site: e.g., the wet season in the Taï Forest [23] versus the dry seasons at Mahale and Gombe (Tanzania) [25,26]. Seasonality was thus hypothesized as an important variable linked causally to chimpanzee predation.

However, more recent studies, including those on other chimpanzee communities, seem to falsify or at least raise doubts about this hypothesis. Data from Taï, Gombe and Mahale [25, 27,28], and especially Ngogo (Kibale National Park, Uganda) [29], where chimpanzee hunting has been sampled in great detail and the most continuously of any site, show that the number of adult males in a group is positively and strongly correlated with hunting frequency [30]. Further, not only do large male groups at Ngogo hunt more frequently, but they also have greater success and a higher rate of multiple kills per predation event than do smaller male groups $[29,30]$. These observations are not surprising, considering that chimpanzees have a strong preference for colobus monkeys (Colobus spp.) as prey. Chimpanzees hunt colobines by arboreal pursuit and manual capture, so multiple converging hunters and the presence of individuals to block escape routes is tied to success [29].

Mitani and Watts [30] contend that hunting serves an intrasexual social function, in which participating males create alliances centered around hunting and, more importantly, meat sharing. The researchers thus suggest that chimpanzee predatory behavior lacks a causal ecological impetus. If correct, this hypothesis would nullify chimpanzees as useful referents for modeling hunting in basal hominids. But, since hunting frequency oscillates throughout the year in studied chimpanzee groups, it begs the fundamental question of whether there is an eco-seasonal component to male aggregation in chimpanzees?

Rather than fruit scarcity, as some older data suggested prompts hunting in chimpanzees, it appears instead that fruit abundance is strong predictor of large male groups at Taï, Gombe, Mahale and Ngogo, and that large male groups, in turn, predict the elevated rate and success of hunting $[24,28,29,31,32]$. Because fruit is a major source of energy, these observations imply that hunting is unlikely motivated by energetic needs. Mitani and Watts [30] thus argue that hunting might be a "luxury activity," engaged in only when fruit availability is at its peak. Ripe fruit attracts aggregations of chimpanzees. Those aggregations can grow expansive because of the sheer abundance of fruit available to support them. With daily energetic needs easily met, large male subgroups can turn to high-cost predation without the risk of energy shortfalls that would be incurred by unsuccessful hunts in periods of fruit scarcity. The evolutionary benefits thus obtained are not immediate energetic returns but, instead, potential long-term gains delivered by coalition membership, e.g., reproductive advantages.

This hypothesis requires additional testing, as does an alternative hypothesis that contends the direct and immediate benefit of hunting is instead nutritional payoff. Energy and nutrients are not synonymous. Stanford et al. [28] stressed that meat provides nutritional elements that other plant resources provide only seasonally. Takahata et al. [25] argued that chimpanzees at Mahale depend more on meat as a protein source in the dry season than during the wet season because leaves, which also provide protein, are scarcer in the 
dry season [24, 33]. Chimpanzee hunting at Taï is more frequent when coula nuts (Coula edulis), a major source of protein and fat, are not in season [23]. The very fact that meat is a successful currency for male-male alliance building and maintenance attests to its intrinsic value to chimpanzees. Considering the properties of meat, it seems to us, that that intrinsic value is largely nutritional: "The possibility that chimpanzees achieve nutritional benefits directly from hunting cannot be easily dismissed. The necessary nutritional studies quantifying chimpanzee diet have not been conducted, and for either of the tradegoods hypotheses to operate, there must be a nutritional gain to the individuals who receive and consume parts of the carcass. If there were not, the carcass would hold no value and could not be traded" [32:1313]. Data are still scant, but recent observations of monkey hunting by bonobos ( $P$. paniscus), a species that lacks male bonding and is less aggressive than the chimpanzee, at LuiKotale (Salonga National Park, Democratic Republic of the Congo) [34] give tentative support to the hypothesis that hunting is primarily nutritionally, rather than socially, driven. Regardless, until comprehensive comparative studies of diet are completed, it is impossible to falsify the hypothesis that hunting is triggered by shortfalls in nutrition instead of energy and its rejection is thus invalidated.

\section{A MODEL OF HUNTING BY BASAL HOMINIDS}

The data reviewed above suggest that nutritional shortfalls, like energetic shortfalls, are probably seasonally regular. In addition, intersite comparison reveals a trend of increased hunting frequency moving from less seasonal to more seasonal environments inhabited by chimpanzees: hunting rates at Ngogo are higher than in the Congo Basin, but lower than at Taï, Gombe and Mahale, and at Taï rates are lower than at Gombe and Mahale $[23,24,28,29]^{1}$. The impact of hunting on populations of colobus monkey prey also reflects this trend. At Ngogo $10-12 \%$ of the total colobus population is killed by chimpanzees annually, while at Taï the range is $3-7 \%$ of the population and at Gombe a staggering $16-40 \%$ of the population is eliminated each year by chimpanzee predation $[23,26,27,29]$. The variety of prey targeted by chimpanzee hunters also increases in more seasonal habitats relative to less seasonal ones. Uehara [24] summarized that woodland chimpanzees hunt a wider range of prey species than those living in forests, such as Lopé (Gabon), NouabaleNdoki and Kahuzi-Biega (Congo), Boussou (Guinea) and Budongo (Uganda). In contrast, chimpanzees at Taï and Ngogo sometimes hunt animals other than monkeys [29] and prey choice is the most diverse at Mahale and Gombe, where 20 different species, including a few genera of artiodactyls, are hunted. Tool-assisted predation on vertebrates is a further cultural elaboration that indicates the importance of hunting at Fongoli (Senegal). Fongoli is a savanna ecosystem that is even more markedly seasonal than other sites, where chimpanzees use tooth-sharpened sticks to spear galagos

\footnotetext{
${ }^{1}$ In contrast to many studied populations of chimpanzees, which commonly inhabit seasonal forests and woodlands, bonobos uniformly occupy dense tropical forests that experience limited seasonality. It is also commonly believed that predation by bonobos is much rarer than by chimpanzees, although Stanford [68] contends that this discrepancy may be more to do with a lack of observational data on bonobos than because of any real difference between them and chimpanzees. Perhaps the recent report of five diurnal, arboreal monkey hunts by bonobos at LuiKotale, [34] lend some credence to this argument, but much more such data is needed to falsify the hypothesis that bonobos hunt and eat meat less frequently than do chimpanzees.
}

(Galago galago) in their tree nests [35]. Together, these observations indicate that the ultimate cause of hunting is probably ecologically and, more specifically, seasonally triggered: meat fulfills nutritional requirements in season(s) when those nutrients are unavailable in other resources, like leaves and nuts.

If confirmed, that means we will be able to employ chimpanzee data in a non-trivial model of early hominid hunting. This is especially so considering that early hominids probably occupied biomes that were at least as seasonal as the most seasonal of those inhabited by extant chimpanzees. It is true that paleoecological data indicating woodland habitats at some of the very earliest hominid localities, like Aramis and the Western Margin of the Middle Awash (Ethiopia) [36,37] and Lukeino (Kenya) [38], falsify strictly constructed savanna hypotheses of human origins $[39,40]$. But, the data also suggest that the woodlands occupied by those hominids were seasonal rather than tropical forests. Further, data from the Western Margin of Gona (Ethiopia) [41,42] and Toros-Menalla (Chad) [43] suggest some Ardipithecus and Sahelanthropus sites were in close proximity to open grasslands. With the emergence of the genus Australopithecus, by at least c. 4.2 Ma, hominid megadontia and dentognathic specialization "indicate an adaptive shift towards the exploitation of tougher and more abrasive food resources. This may signal an 'ecological breakout' involving niche expansion with intensified exploitation of more open African Pliocene habitats" [44: 888].

As reviewed above, there is, to date, no direct evidence of hunting (or scavenging) by hominids prior to $2.6 \mathrm{Ma}$, when the earliest known archaeological occurrences include stone cutting and hammering tools and animal bones with butchering marks from the use of those tools to render carcasses $[3,4]$. However, based on isotopic studies, a significant degree of faunivory is inferred for some australopithecines [45-47]. Whether that faunivory is more specifically insectivory or eating of $\mathrm{C}_{4}$-consuming ungulates is debated. The equivocation does not permit falsification of a meateating hypothesis for pre-lithic hominids.

Working from a chimpanzee model and isotopic results that point toward meat as a dietary requirement for largebodied hominoids in seasonal habitats, with oscillating availability of nutrients (e.g., protein) from plants, we predict hunting, rather than scavenging, by basal hominids under these ecological conditions. Studies of carcass persistence in modern savannas demonstrate that scavengeable meat is rarely available and, thus, scavenging opportunities there are largely limited to bone grease and marrow $[48,49]$. Hominids, past and present, require pounding tools (e.g., hammerstones) to access these within-bone carcass resources, but no hammerstones or hammerstone damage have been found in the paleoanthropological record prior to $2.6 \mathrm{Ma}$. In the additional absence of cutting tools and cutmarks, we suggest tentatively that pre-lithic hominids likely hunted small animals, which did not require extrasomatic processing to consume.

Given the unique locomotor adaptations of early hominids [50,51], it is more challenging-but certainly not impossible - to model how they may have executed hunts. As the spear-hunting chimpanzees of Fongoli demonstrate, one need not be terrestrially fleet-footed or particularly agile arboreally to be a regularly successful small-game hunter. 
Likewise, sessile infant mammals, concealed but undefended by their foraging mothers, could have been targeted by hunting hominids. More investigation is clearly needed in these areas. For example, early hominids may have hunted (at least sometimes) using rudimentary, perishable weaponry. The more recent, Plio-Pleistocene archaeological records at Koobi Fora and at Peninj (Tanzania) preserve evidence of woodworking (including possible spear production) in, respectively, the form of wear polish and adhering phytoliths on stone tool edges [52,53]. But, the tooth-sharpened spears of the Fongoli chimpanzees demonstrate the effectiveness of organic stabbing weaponry, completely unmodified by stone. The Fongoli data also highlight another important aspect of even the simplest extrasomatic hunting technology-it provides at least some measure of distance between predator and prey. This is important because even small prey, like galagos, can inflict counterattacking injuries upon a predator. And even seemingly insignificant wounds have the potential to go septic and become life-threatening to a predator. Finally, spear-hunting by the Fongoli chimpanzees weakens paleoanthropological orthodoxy that declares spear hunting was beyond the conceptual grasp and technological capabilities of early hominids. But, the most important concluding point is that a model of hunting by pre-lithic hominids, built on linked non-trivial analogies, exposes the widespread sentiment that before evidence of carcass butchery, at $2.6 \mathrm{Ma}$, "vertebrate meat [was] likely a small dietary component [and] could have been garnered via scavenging as opposed to hunting" [7: 95] as scientifically unfounded.

\section{TEST IMPLICATIONS}

Predation and the manual and oral processing and consumption of small (perhaps predominantly immature) prey by Mio-Pliocene hominids will be difficult—but not necessarily impossible-to detect in a pre-lithic archaeological record, if such a record exists. Studies of faunal accumulations created by chimpanzee hunting and carcass consumption [54-56] are steadily providing non-trivial analogies to characterize bone assemblages of small prey captured and processed by hominoids without tools. Further, using the dimensions of tooth marks to identify the taxa of their creators is an analytical tool that is becoming increasingly refined [57-60], and one that holds great potential for isolating a "hominoid-pattern." This is especially so when such observations are combined with other taxon-specifying taphonomic criteria [61], in the sense of a classic Binfordian [62] configurational approach to faunal analysis. More particularly, recent work is focusing on identifying diagnostic features of human-produced tooth marks on bones [63,64].

The stereotype that the fossil and archaeological records are uniformly biased in favor of remains from large animals is unfounded. For example, Pleistocene cave deposits in South Africa yield abundances of microvertebrate fossils of amphibians, reptiles, rodents and bats, as do many open-air localities in East Africa. Juvenile remains of larger animals are also represented, for example, at Kanjera South (Excavation 1), a c. 2.0 Ma site in western Kenya. The faunal assemblage from that site contains a large proportion $(39 \%$ of the total assemblage) of remains from animals larger than microvertebrates but still of relatively small size, with estimated live weights for individuals of $<72 \mathrm{~kg}[65,66]$. Further, initial estimates are that up to $50 \%$ of that "small ani- mal" subassemblage is comprised of remains from juveniles [66]. Definitive causal links between these remains and hominid predation and meat-eating - in the form of butchery marks or other diagnostic indicators-have not yet been presented and Kanjera is also $\sim 5$ million years younger than deposits that are yielding the earliest hominid remains. However, the important point here is that the Kanjera evidence demonstrates the possibility, if even rare, of the kind of preservation in a hominid context that we seek and we need to test the model of basal hominid hunting and meat-eating elaborated in this paper.

Considering the disparate locomotor patterns of chimpanzees and basal hominids, predictions of arboreal primate hunting by the latter seem to emanate from a trivial, and thus, specious analogy. That said, we note that samples are available to test this prediction. For example, colobines are the most abundant taxon, comprising $>30 \%$ of the collected vertebrate faunal specimens, in the Ar. ramidus-bearing stratum (i.e., between the Daam Aatu Basaltic Tuff and Gáala Vitric Tuff Complex) at the Aramis localities [36]. If and when hominoid-specific toothmarks are classified those observations can be applied to the Aramis primate samples, as well as other samples that become available.

\section{CONCLUSIONS}

As the new functional morphology data for Ar. ramidus highlight so emphatically, many of the morphological and behavioral adaptations (and ecological circumstances) of our Mio-Pliocene forebears are distinctly un-replicable. But in the absence of time travel, paleoanthropologists can still rely on actualistic approaches to reconstruct some important aspects of the biology of prehistoric hominids. Hard-line conceptual modelers bristle at the prominence of chimpanzees in many such reconstructions. They advocate, instead, "strategic" models, based on evolutionary and ecological principles. But, of course, hard data demonstrating those principles are necessarily drawn from specific, observable (i.e., extant) referents. So, to assert that conceptual models eschew referential bases is spurious.

Recognizing this fact, some proponents of conceptual modeling take pains to display taxonomic objectivity and cast widely, employing diverse referents in support of overarching evolutionary principles. In some cases those efforts are theoretically secure, but in others they are not. Specifically, when referent taxa reside in radically dissimilar ecologies and/or are phylogenetically distant from the extinct study subject it renders the resulting analogies trivial and substantively uninformative. It thus seems to us that we turn our backs on those couple, most exceptionally relevant extant taxa (culture-bearing chimpanzees and humans) at our own expense and in defiance of pragmatism.

The model of basal hominid hunting presented heresmall animal prey in a seasonal savanna habitat, harvested and processed by hominids using their hands and mouths and, perhaps, perishable organic technology, like wooden sticks-is not novel. Louis Leakey, for one, relished his skill at catching springhares (Pedetes capensis) and small antelopes by hand, and argued early hominids would have been just as capable [67]. We do, however, provide the first stepby-step presentation of the hypothesis, complete with its non-trivial analogical bases fully explicated. Challenges re- 
main, the most obvious being the vagaries of the fossil record. That, however, is the case with using the paleoanthropological record to test any hypothesis of human evolution. Some gaps, because they are real features of the record, will never be closed. But, an academic culture in paleoanthropology that endorses fieldwork in theory, spirit and finances will close the others. And a more comprehensive and credible picture of human evolution will hopefully follow.

\section{ACKNOWLEDGEMENTS}

TRP thanks his family and MD-R thanks M. Prendergast for their unfailing support. Thanks to Jill Pruetz for her encouragement and insightful comments on an earlier draft of the paper, as well as to John Fleagle and three anonymous readers for their input.

\section{REFERENCES}

[1] Milton K. Hunter-gatherer diets: wild foods signal relief from diseases of affluence. In: Ungar P, Teaford M, Eds. Human diet: its origins and evolution. Bergin and Garvey, Westport (CT) 2002; pp. 111-22.

[2] Semaw S, Rogers MJ, Quade J, et al. 2.6-million-year-old stone tools and associated bones from OGS-6 and OGS-7, Gona, Afar, Ethiopia. J Hum Evol 2003; 45: 169-77.

[3] Domínguez-Rodrigo M, Pickering TR, Semaw S, Rogers MJ. Cutmarked bones from Pliocene archaeological sites at Gona, Afar, Ethiopia: implications for the function of the world's oldest stone tools. J Hum Evol 2005; 48:109-21.

[4] de Heinzelin J, Clark JD, White T, et al. Environment and behaviour of 2.5-million-year-old Bouri hominids. Science 1999; 284: 625-9.

[5] Bunn HT. Meat made us human. In: Ungar P, Ed. Early hominin diets: the known, the unknown, and the unknowable. Oxford: Oxford University 2006; pp. 191-211.

[6] Tooby J, DeVore I. The reconstruction of hominid behavioral evolution through strategic modeling. In: Kinzey W, Ed. The evolution of human behavior: primate models. Albany State: University of New York Press 1987; pp. 183-237.

[7] Sayers K, Lovejoy CO. The chimpanzee has no clothes: a critical examination of Pan troglodytes in models of human evolution. Curr Anthropol 2008; 49: 87-114.

[8] Goodman M. The genomic record of humankind's evolutionary roots. Am J Hum Genet 1999; 64: 31-9.

[9] McBrearty S, Jablonski NG. First fossil chimpanzee. Nature 2005; 437: 105-7.

[10] White TD, Asfaw B, Beyene Y, et al. Ardipithecus ramidus and paleobiology of early hominids. Science 2009; 326: 75-86.

[11] Wobst M. The archaeo-ethology of hunter-gatherers or the tyranny of the ethnographic record in archaeology. Am Antiquity 1978; 43: 303-9.

[12] Lyman RL. Vertebrate taphonomy. Cambridge, England: Cambridge University Press 1994

[13] Aronson JL, Harré R, Cornell Way E. Realism rescued: how scientific progress is possible. London, England: Open Court 1995.

[14] Bunge M. Chasing reality: strife over realism. Toronto, Canada: University of Toronto Press 2006.

[15] Gifford D. Taphonomy and paleocology: a critical review of archaeology's sister disciplines. In: Schiffer M, Ed. Advances in archaeological method and theory. New York: Academic Press 1981; vol. 4: pp. 365-438.

[16] Gifford-González D. Bones are not enough: analogues, knowledge, and interpretive strategies in zooarchaeology. J Anthropol Archaeol 1991; 10: 215-54.

[17] Harré R.Varieties of realism. Oxford, England: Blackwell 1986.

[18] Carvalho S, Cunha E, Sousa C, Matsuzawa T. Chaînes opératoires and resource exploitation strategies in chimpanzee (Pan troglodytes) nut cracking. J Hum Evol 2008; 55:148-63.

[19] Semaw S. The world's oldest stone artefacts from Gona, Ethiopia: their implications for understanding stone technology and patterns of human evolution between 2.6-1.5 million years ago. J Achaeol Sci 2000; 27:1197-214.
[20] Stout D, Quade J, Semaw S, Rogers M, Levin N. Raw material selectivity of the earliest stone toolmakers at Gona, Afar, Ethiopia. J Hum Evol 2005; 48: 365-80.

[21] Toth N, Schick K, Semaw S. A comparative study of the stone tool-making abilities of Pan, Australopithecus and Homo sapiens. In: Toth N, Schick K, Eds. The Oldowan: case studies into the Earliest Stone Age. Stone Age Institute: Bloomington 2006; pp. $155-222$.

[22] Mercader J, Panger M, Boesch C. Excavation of a chimpanzee stone tool site in the African rainforest. Science 2002; 296:1452-5.

[23] Boesch C, Boesch H. Hunting behavior of wild chimpanzees in the Taï National Park. Am J Phys Anthropol 1989; 78: 547-73.

[24] Uehara S. Predation on mammals by the chimpanzee (Pan troglodytes). Primates 1997; 38:193-214.

[25] Takahata Y, Hasegawa T, Nishida T. Chimpanzee predation in the Mahale Moutains from August 1979 to May 1982. Int J Primatol 1984; 5: 213-23.

[26] Stanford CB. Chimpanzee and red colobus: the ecology of predator and prey. Cambridge USA: Harvard University Press 1998.

[27] Boesch C. Cooperative hunting in wild chimpanzees. Anim Behav 1994; 48: 653-67.

[28] Stanford CB, Wallis J, Matama H, Goodall J. Patterns of predation by chimpanzees on red colobus monkeys in Gombe National Park, Tanzania, 1982-1991. Am J Phys Anthropol 1994; 94: 213-28.

[29] Watts D, Mitani JC. Hunting and meat sharing by chimpanzees at Ngogo, Kibale National Park, Uganda. In: Boesch C, Hohmann G, Marchant L. Eds., Behavioral diversity in Chimpanzees and bonobos. Cambridge: Cambridge University Press 2001; pp. 24455 .

[30] Mitani JC, Watts D. Why do chimpanzees hunt and share meat? Anim Behav 2001; 61: 915-24.

[31] Wrangham R. Feeding behaviour of chimpanzees in Gombe National Park, Tanzania. In: Clutton-Brock T, Ed. Primate ecology. London: Academic Press 1977; pp. 503-38.

[32] Newton-Fisher NE. Chimpanzee hunting behaviour. In: Henke W, Tattersall I, Eds. Handbook of paleoanthropology. USA: Springer 2007; pp. 1295-320.

[33] Hladik CM. Chimpanzees of Gabon and chimpanzees of Gombe: some comparative data on the diet. In: Clutton-Brock T Ed. Primate ecology. London: Academic Press 1977; pp. 481-501.

[34] Surbeck M, Hohmann G. Primate hunting by bonobos at LuiKotale, Salonga National Park. Curr Biol 2008; 18: 906-7.

[35] Pruetz JD, Bertolani P. Savanna chimpanzees, Pan troglodytes verus, hunt with tools. Curr Biol 2007; 17:1-6.

[36] WoldeGabriel G, White TD, Suwa G, et al. Ecological and temporal placement of Early Pliocene hominids at Aramis, Ethiopia. Nature 1994; 371: 330-3.

[37] WoldeGabriel G, Haile-Selassie Y, Renne PR, et al. Geology and palaeontology of the Late Miocene Middle Awash Valley, Afar Rift, Ethiopia. Nature 2001; 412: 175-8.

[38] Pickford M, Senut B. The geological and faunal context of Late Miocene hominid remains from Lukeino, Kenya. CR Acad Sci Ser IIa 2001; 332: 145-52.

[39] Darwin C. The descent of man and selection in relation to sex. London, England: J Murray 1871.

[40] Dart RA. Australopithecus africanus, the man-ape of South Africa. Nature 1925; 115: 195-9.

[41] Semaw S, Simpson SW, Quade J, et al. Early Pliocene hominids from Gona, Ethiopia. Nature 2005; 433: 301-5.

[42] Levin NE, Simpson SW, Quade J, Cerling TE, Frost SR. Herbivore enamel carbon isotopic composition and the environmental context of Ardipithecus at Gona, Ethiopia. Geol Soc Am Spec Pap 2008; 446: 215-34.

[43] Vignaud P, Duringer P, Mackaye HT, et al. Geology and palaeontology of the Upper Miocene Toros-Menalla hominid locality, Chad. Nature 2002; 418: 152-55.

[44] White TD, WoldeGabriel G, Asfaw B, et al. Asa Issie, Aramis and the origin of Australopithecus. Nature 2006; 440: 883-9.

[45] van der Merwe NJ, Thackeray JF, Lee-Thorp JA, Luyt J. The carbon isotope ecology and diet of Australopithecus africanus at Sterkfontein, South Africa. J Hum Evol 2003; 44: 581-97.

[46] Sponheimer M, Lee-Thorp J, de Ruiter D, et al. Hominins, sedges, and termites: new carbon isotope data from the Sterkfontein Valley and Kruger National Park. J Hum Evol 2005; 48:301-312.

[47] Sponheimer M, Lee-Thorp J, de Ruiter D Icarus. Isotopes, and australopith diets. In: Ungar P, Ed. Evolution of the human diet: the 
known, the unknown, and the unknowable. Oxford: Oxford, University Press 2007; pp. 1321-49.

[48] Blumenschine R. Characteristics of an early hominid scavenging niche. Curr Anthropol 1987; 28: 383-407.

[49] Domínguez-Rodrigo M. Hunting and scavenging by early humans: the state of the debate. J World Prehistory 2002; 16:1-54.

[50] Lovejoy CO, Suwa G, Spurlock L, Asfaw B, White TD. The pelvis and femur of Ardipithecus ramidus: the emergence of upright walking. Science 2009a; 326:71e1-71e6.

[51] Lovejoy CO, Simpson SW, White TD, Asfaw B, Suwa G. Careful climbing in the Miocene: the forelimbs of Ardipithecus ramidus and humans are primitive. Science 2009b; 326: 70e1-70e8.

[52] Keeley LH, Toth N. Microwear polishes on early stone tools from Koobi Fora, Kenya. Nature 1981; 293: 464-5.

[53] Domínguez-Rodrigo M, Serrallonga J, Juan-Treserras J, Alcalá L, Luque L. Woodworking activities by early humans : a plant residue analysis on Acheulian stone tools from Peninj (Tanzania). J Hum Evol 2001; 40: 289-99.

[54] Pickering TR, Wallis J. Bone modifications resulting from captive chimpanzee mastication: implications for the interpretation of Pliocene archaeological faunas. J Archaeol Sci 1997; 24: 1115-27.

[55] Plummer TW, Stanford CB Analysis of a bone assemblage made by chimpanzees at Gombe National Park, Tanzania. J Hum Evol 2000; 39: 345-65.

[56] Pobiner B, DeSilva J, Sanders WJ, Mitani JC. Taphonomic analysis of skeletal remains from chimpanzee hunts at Ngogo, Kibale National Park, Uganda. J Hum Evol 2007; 52: 614-636.

[57] Haynes G. A guide for differentiating mammalian carnivore taxa responsible for gnaw damage to herbivore limb bones. Paleobiol 1983; 9:164-72.

[58] Selvaggio MM, Wilder J Identifying the involvment of multiple carnivore taxa with archaeological bone assemblages. J Archaeol Sci 2001; 28: 465-70.
[59] Domínguez-Rodrigo M, Piqueras A. The use of tooth pits to identify carnivore taxa in tooth-marked archaeofaunas and their relevance to reconstruct hominid carcass processing behaviours. J Archaeol Sci 2003; 30:1385-91.

[60] Pickering TR, Domínguez-Rodrigo M, Egeland CP, Brain CK. Beyond leopards: tooth marks and the relative contribution of multiple carnivore taxa to the accumulation of the Swartkrans Member 3 fossil assemblage. J Hum Evol 2004; 46: 595-604.

[61] Pobiner B, Blumenschine RJ. A taphonomic perspective on Oldowan hominid Encroachment on the carnivoran paleoguild. J Taphonomy 2003; 1: 115-41.

[62] Binford LR. Bones: ancient men and modern myths. New York, USA: Academic Press 1981

[63] Landt MJ. Tooth marks and human consumption: ethnoarchaeological mastication research among foragers of the Central African Republic. J Archaeol Sci 2007; 34:1629-40.

[64] White TD, Toth N. Carnivora and carnivory: assessing hominid toothmarks in zooarchaeology. In: Pickering TR, Schick, K, Toth $\mathrm{N}$, Eds. Breathing life into fossils: taphonomic studies in honor of C.K. (Bob) Brain. Stone Age Institute: Bloomington 2007; pp. 20116.

[65] Bishop LC, Plummer TW, Ferraro JV, et al. Recent research into Oldowan hominin activities at Kanjera South, western Kenya. Afr Archaeol Rev 2006; 23: 31-40.

[66] Plummer TW. Flaked stones and old bones: biological and cultural evolution at the dawn of technology. Yearbook of Physical Anthropology 2004; 47: 118-64.

[67] Morell V. Ancestral passions: the Leakey family and the quest for humankind's beginnings. New York, USA: Simon and Schuster 1995.

[68] Stanford CB. The social behavior of chimpanzees and bonobosempirical evidence and shifting assumptions. Curr Anthropol 1998b; 39: 399-420.

(C) Pickering and Manuel Domínguez-Rodrigo; Licensee Bentham Open.

This is an open access article licensed under the terms of the Creative Commons Attribution Non-Commercial License (http://creativecommons.org/licenses/by-nc/3.0/) which permits unrestricted, non-commercial use, distribution and reproduction in any medium, provided the work is properly cited. 